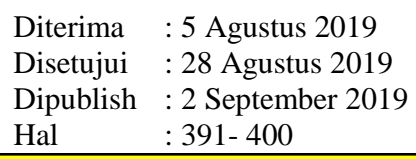

\title{
PERJANJIAN TINDAKAN MEDIS ANTARA DOKTER DENGAN PASIEN SEBAGAI BENTUK PELAYANAN PUBLIK
}

\author{
GEDE TUSAN ARDIKA \\ Fak. Hukum UNMAS Denpasar PSDKU Mataram \\ e-mail : gedetusan @gmail.com
}

\begin{abstract}
ABSTRAK
Tujuan penulisan ini adalah untuk mengetahui prosedur pembuatan perjanjian dalam tindakan medis pada pelayanan kesehatan antara dokter dengan pasien dalam penanganan tindakan medis. Penelitian merupakan penelitian hukum normatif dengan studi pendekatan berdasarkan peraturan perundang-undangan, pendekatan konseptual, dan pendekatan kasus.

Dari hasil penelitian dapat disimpulkan bahwa, Perjanjian Tindakan Medis (informed consent) dilaksanakan sesuai dengan prosedur peraturan perundangan, untuk itu dokter terikat dengan kode etik profesi dalam melaksanakan fungsinya sebagai tenaga medis, sehingga dalam melaksanakan tindakan medis harus ada kata sepakat dan tertulis antara dokter dengan pasiennya. Akibat hukum yang timbul antara dokter dengan pasien setelah tindakan medis dilaksanakan adalah berupa tanggung jawab hukum, baik dalam bentuk hukum perdata, pidana dan administrasi terkait dengan profesinya.
\end{abstract}

Kata kunci: Perjanjian, tindakan medis

\section{ABSTRACT}

The purpose of this paper is to find out the procedure for making agreements in medical actions in health services between doctors and patients in handling medical measures. The research is a normative legal research study with an approach based on laws and regulations, a conceptual approach and a case approach.

From the results of the study it can be concluded that, the Agreement on Medical Action (informed consent) is carried out in accordance with statutory procedures, for that doctors are bound by professional code of ethics in carrying out their functions as medical personnel, so that in carrying out medical actions there must be an agreement and written agreement between the doctor and the patient. The legal consequences arising between the doctor and the patient after the medical action is carried out are in the form of legal responsibility, both in the form of civil, criminal and administrative law related to his profession.

Keywords: Agreement, medical treatment

\section{PENDAHULUAN}

\section{Latar Belakang}

Kewajiban pemerintah adalah memberikan pelayanan publik kepada masyarakat, karena itu adalah hak masyarakat, maka setidak-tidaknya pelayanan publik tersebut harus memiliki standar minimal yang harus disyaratkan agar supaya memenuhi harapan masyarakat. Standar pelayanan dimaksud, sekurangkurangnya meliputi (1) Prosedur pelayanan (prosedur pelayanan yang dilakukan bagi pemberi dan penerima pelayanan termasuk pengaduan), (2) Waktu penyelesaian (waktu penyelesaian yang ditetapkan sejak saat pengajuan permohonan sampai dengan penyelesaian pelayanan termasuk pengaduan), (3) Biaya pelayanan 
biaya / tariff pelayanan termasuk perinciannya yang ditetapkan dalam proses pemberian pelayanan), (4) Produk pelayanan ( hasil pelayanan yang akan diterima sesuai dengan ketentuan yang telah ditetapkan), (5) Sarana dan prasarana ( penyediaan sarana dan Prasarana pelayanan yang memadai oleh penyelenggara pelayanan publik), (6) Kompetensi Petugas pemberi pelayanan ( kompetensi petugas pemberi pelayanan harus ditetapkan dengan tepat berdasarkan pengetahuan keahlian keterampilan sikap dan perilaku yang dibutuhkan)

Rumah Sakit merupakan satu dari bagian pelayanan publik. Jika dicermati maka Pelayanan publik merupakan sebuah kewajiban bagi pemerintah, namun sebaliknya menjadi hak bagi masyarakat, untuk memperoleh dan menyelenggarakan pelayanan publik yang baik, maka pelayanan publik tersebut harus memiliki standar minimal yang harus disyaratkan supaya memenuhi harapan masyarakat.

Untuk mewujudkan derajat kesehatan yang optimal, peran serta Pemerintah dapat terlihat dengan lahirnya Undang-Undang Nomor 6 Tahun 1963 tentang Tenaga Kesehatan. Selama kurun waktu yang cukup lama ilmu kesehatan hampir tidak ada perkembangan lebih khusus dalam bidang ilmu hukum kesehatan.Perkembangan secara terpadu dimulai sejak tahun 1978, yaitu sejak dikeluarkannya Ketetapan Majelis Permusyawaratan Rakyat Republik Indonesia Nomor IV/MPR/1978 tenting Garis-garis Besar Haluan Negara dan Keputusan Presiden Nomor 7 Tahun 1979 tentang Repelita III. Pada tahun 1982 dengan keluarnya Surat Keputusan Menteri Kesehatan RI. No. 99a/Menkes/1II/1982 tentang berlakunya Sistem Kesehatan Nasional. Hal ini merupakan perwujudan dari Pembukaan Undang-Undang Dasar 1945 yang tercantum tujuan nasional dari Bangsa Indonesia, yaitu: "membentuk suatu pemerintahan Negara Indonesia yang melindungi segenap bangsa Indonesia, memajukan kesejahteraan umum, mencerdaskan kehidupan bangsa serta ikut melaksanakan ketertiban dunia yang berdasarkan kemerdekaan, perdamaian abadi, dan keadilan sosial yang berdasarkan Pancasila". Untuk mencapai tujuan nasional tersebut diselenggarakan upaya pembangunan yang berkesinambungan yang merupakan suatu rangkaian pembangunan yang menyeluruh, terarah, terpadu, termasuk diantaranya pembangunan kesehatan

Dengan Lahirnya Undang-Undang Nomor 23 Tahun 1992 tentang Kesehatan merupakan bukti bahwa hukum kesehatan mulai perlahan-lahan mendapat tempat di dalam perkembangan hukum di Indonesia. Hukum kesehatan merupakan suatu bidang studi spesialisasi ilmu hukum yang secara relatif masih baru bagi bangsa Indonesia. Sejak itu kesehatan menempati bagian tersendiri dalam pembangunan nasional secara keseluruhan. Hal ini terlihat di dalam Rencana Strategi Departemen Kesehatan (Renstra Depkes) tahun 2005-2009, disebutkan pembangunan kesehatan di Indonesia dalam tiga dekade ini yang dilaksanakan secara berkesinambungan telah cukup berhasil meningkatkan derajat kesehatan. Namun demikian, derajat kesehatan di Indonesia tersebut masih terhitung rendah apabila dibandingkan dengan negara-negara tetangga. Sesuai dengan Undang-Undang Nomor 17 Tahun 2007 tentang Rencana Jangka Panjang Pembangunan Nasional (RJPN) tahun 2005-2025, pembangunan kesehatan diarahkan untuk meningkatkan kesadaran, kemauan hidup sehat bagi setiap orang. Hal ini dimaksudkan agar peningkatan derajat kesehatan yang setinggitingginya dapat terwujud. Dalam dua puluh tahun terakhir, pembangunan kesehatan yang diselenggarakan secara berkesinambungan, berkelanjutan, menyeluruh, terarah dan terintegrasi didasarkan pada Sistem Kesehatan Nasional (SKN) yang telah ditetapkan pada tahun 2009.

Pelayanan kesehatan (medis) merupakan hal yang penting yang harus dijaga maupun ditingkatkan kualitasnya sesuai standar pelayanan yang berlaku agar masyarakat dapat merasakan pelayanan yang diberikan. Pelayanan sendiri hakikatnya merupakan suatu usaha.untuk membantu menyiapkan segala sesuatu yang diperlukan orang lain serta dapat memberkan kepuasan sesuai dengan keinginan yang diharapkan oleh konsumen. Terdapat tiga komponen yang terlibat dalam suatu proses pelayanan yakni, pelayanan sangat ditentukan oleh kualitas pelayanan yang diberikan, siapa yang melakukan layanan, dan konsumen yang menilai suatu pelayanan melalui harapan yang diinginkannya.

Tenaga medis khususnya adalah tenaga profesional yang bertugas dalam pelayanan kesehatan dan dalam menjalankan tugas dan wewenangnya terikat dengan kode etik profesi maupun peraturan perundang undangan yang berlaku. Dengan demikian dalam menjalankan tugas pokok fungsinya, tenaga medis senantiasa berpedoman pada prosedur, petunjuk teknis, petunjuk pelaksanaan. Berdasarkan uraian diatas, penulis tertarik untuk meneliti tentang pelayanan medis yang dilakukan oleh dokter terhadap pasiennya yang dirawat di rumah sakit. Adapun judul yang penulis angkat adalah "Perjanjian Tindakan Medis Antara Dokter Dengan Pasien sebagai bentuk pelayanan publik". 


\section{Rumusan Masalah}

Berdasarkan latar belakang divatas, maka dapat dirumuskan beberapa permasalahan yang hendak diteliti, yaitu: Bagaimana prosedur pelaksanaan Perjanjian Tindakan Medis dan apa akibat hukum dari Perjanjian Tindakan Medis dokter terhadap pasien yang dirawat di Rumah Sakit?

\section{Tujuan dan Manfaat Penelitian}

Tujuan penulisan penelitian ini, antara lain:

1. Untuk mengetahui prosedur pelaksanaan Perjanjian Tindakan Medis.

2. Untuk Mengetahui akibat hukum dari Perjanjian Tindakan Medis dokter terhadap pasien yang dirawat di Rumah Sakit.

1. Manfaat teoritis

Penelitian ini diharapkan dapat memberikan manfaat berupa:

Penulisan ini diharapkan dapat memberikan sumbangan pengetahuan yang bermanfaat bagi perkembangan ilmu hukum pada umumnya dan hukum kesehatan pada khususnya yang berhubungan dengan Perjanjian Tindakan Medis (informed consent)

2. Manfaat Praktis

Penelitian ini diharapkan dapat memberikan wawasan kepada semua pihak antara lain kepada para pelaksana medis khususnya dokter maupun masyarakat umum khususnya bagi pasien yang dirawat di rumah sakit dan keluarganya tentang Perjanjian Tindakan Medis (informed consent).

\section{METODE PENELITIAN}

Penelitian ini merupakan penelitian hukum normatif. Penelitian hukum normatif adalah penelitian yang mencakup asas-asas hukum, penelitian terhadap sistematika hukum, penelitian terhadap taraf sinkronisasi hukum, dan penelitian terhadap sejarah hukum. Menurut Amirudin dan Zainal Asikin, penelitian normatif hanya mengenal data sekunder saja, yang terdiri dari: bahan hukum primer, bahan hukum sekunder, dan bahan hukum tersier, maka oleh karena itu dalam mengolah dan menganalisis bahan hukum tersebut tidak bisa melepaskan diri dari berbagai penafsiran yang dikenal dalam ilmu hukum.

\section{HASIL PENELITIAN DAN PEMBAHASAN}

\section{Prosedur Pelaksanaan Perjanjian Tindakan Medis terhadap pasien}

Berdasarkan jenis pelayanan yang diberikan, rumah sakit dikategorikan dalam Rumah Sakit Umum dan Rumah Sakit Khusus. Rumah Sakit Umum memberikan pelayanan kesehatan pada semua bidang dan jenis penyakit, sedangkan Rumah Sakit Khusus memberikan pelayanan utama pada satu bidang atau satu jenis penyakit tertentu berdasarkan disiplin ilmu, golongan umur, organ, jenis penyakit, atau kekhususan lainnya.

Berdasarkan pengelolaannya Rumah Sakit dapat dibagi menjadi Rumah Sakit publik dan Rumah Sakit privat. Rumah Sakit publik dapat dikelola oleh pemerintah, pemerintah daerah, dan badan hukum yang bersifat nirlaba yang dikenal dengan nama Badan Layanan Umum atau Badan Layanan Umum Daerah yang tidak dapat dialihkan menjadi rumah sakit privat. Ketentuan tentang BLUD diatur oleh Peraturan Pemerintah Nomor 23 Tahun 2005 serta Permendagri Nomor 61 Tahun 2007. Sedangkan rumah sakit privat sebagaimana dimaksud dikelola oleh badan hukum dengan tujuan profit yang berbentuk Perseroan Terbatas atau Persero.

Rumah Sakit dapat ditetapkan menjadi rumah sakit pendidikan setelah memenuhi persyaratan dan standar rumah sakit pendidikan.Rumah sakit pendidikan merupakan rumah sakit yang menyelenggarakan pendidikan dan penelitian secara terpadu dalam bidang pendidikan profesi kedokteran, pendidikan kedokteran berkelanjutan, dan pendidikan tenaga kesehatan lainnya.Dalam penyelenggaraan Rumah Sakit Pendidikan dapat dibentuk Jejaring Rumah Sakit Pendidikan.

Klasifikasi Rumah Sakit umum terdiri atas: Rumah Sakit umum kelas A, B, C, dan D. Sedangkan klasifikasi Rumah Sakit khusus mulai dari rumah sakit khusus kelas A, B, serta C. Penyelenggara Rumah Sakit wajib memiliki izin yang terdiri dari izin mendirikan dan izin operasional. Izin rumah sakit kelas A dan 
rumah sakit penanaman modal asing atau penanaman modal dalam negeri diberikan oleh menteri setelah mendapatkan rekomendasi dari pejabat yang berwenang di bidang kesehatan pada Pemerintah Daerah Provinsi. Untuk rumah sakit penanaman modal asing atau penanaman modal dalam negeri diberikan setelah mendapat rekomendasi dari instansi yang rnelaksanakan urusan penanaman modal asing atau penanaman modal dalam negeri.

Untuk menilai tingkat keberhasilan atau memberikan gambaran tentang keadaan pelayanan di rumah sakit serta memberikan informasi yang dapat bermakna dapat diketahui dari tingkat pemanfaatan, mutu, efisiensi pelayanan rumah sakit yang didukung oleh beberapa indicator antara lain : Pelayanan Rawat Inap ,Pelayanan Kegawat Daruratan, Pelayanan Rawat Jalan, Pemeriksaan Laboratorium, Kegiatan Penunjang Medis".

Dalam Prosedur Pelaksanaan Perjanjian Tindakan Medis (Informed Consent) menurut pandangan penulis, ada beberapa hal yang umum berlaku antara lain :

1. Dokter terikat dengan kode etik profesi dalam melaksanakan tugas pokok fungsinya sebagai tenaga medis

2. Dokter yang bertugas di Rumah Sakit dalam melakukan perawatan dan tindakan medis mempunyai hak dan kewajiban

3. Pasien yang dirawat dirumah sakit disamping mempunyai hak juga mempunyai kewajiban pada saat menjalani perawatan di dirumah sakit

4. Tindakan- tindakan medis yang akan dilaksanakan melibatkan dokter dan pasien yang dirawat, harus ada kata sepakat untuk tindakan yang tidak infasif dan tertulis untuk tindakan infasif dan dilaksanakan oleh kedua belah pihak

5. Akibat hukum bagi para pihak, yaitu dokter dan pasien setelah tindakan medis dilaksanakan

Dokter sebagai tenaga profesional adalah bcrtanggung jawab dalam setiap tindakan medis yang dilakukan terhadap pasien. Dalam menjalankan tugas sebagai tenaga medis, maka dokter disamping berlandaskan pada peraturan perundangan yang mengatur tentang kesehatan, juga berpedoman pada kode etik profesi sebagai seorang tenaga medis

Dalam menjalankan profesi kedokteran. Tenaga Kesehatan diatur dalam Pasal 1 Angka 1 Peraturan Pemerintah Nomor 32 Tahun 1996 tentang Tenaga Kesehatan, yang menyatakan bahwa: "Tenaga kesehatan adalah setiap orang yang mengabdikan diri dalam bidang kesehatan serta memiliki pengetahuan dan atau keterampilan melaui pendidikan dibidang kesehatan yang untuk jenis tertentu memerlukan kewenangan untuk melakukan upaya kesehatan." Tenaga Kesehatan terdiri dari: a).Tenaga Kesehatan, b).Tenaga Keperawatan,c).Tenaga Kefarmasian, d).Tenaga Kesehatan Masyarakat, e).Tenaga Gizi,6).Tenaga Ketrampilan Fisik, f).Tenaga Keteknisan Medis

Dalam Undang Undang No 29 Tahun 2004 tentang Praktik Kedokteran secara eksplisit memberikan batasan atau definisi tentang tenaga kesehatan. Dalam penjelasan umum dinyatakan bahwa: dokter dan dokter gigi sebagai salah satu komponen utama pemberi pelayanan kesehatan kepada masyarakat mempunyai peranan yang sangat penting karena terkait langsung dengan pemberian pelayanan kesehatan

Kode etik dokter di Indonesia diatur secara khusus dalam Kode Etik Kedokteran Indonesia (KODEKI). KODEKI pertama kali disusun pada tahun 1969 da!am Musyawarah Kerja Susila Kedokteran di Jakarta, dengan bahan rujukan Kode Etik Kedokteran Internasional yang disempurnakan tahun 1968. KODEKI dinyatakan berlaku bagi semua dokter di Indonesia melalui Keputusan Menteri Kesehatan RI Nomor434/MENKES/ SK/X/1983 tanggal 28 Oktober 1983 KODEKI telah mengalami beberapa kali perubahan dan perubahan terakhir ditetapkan tanggal 19 April 2002 di Jakarta sebagai hasil Musyawarah Kerja Nasional Etik Kedokteran III tahun 2001. Sebagai pedoman perilaku doktcr, KODEKI terdiri dari pasal-pasal yang dapat dibagi menjadi 5 bagian, yaitu:

1) Kewajiban umum seorang dokter (sembilan pasal)

2) Kewajiban dokter terhadap penderita (lima pasal)

3) Kewajiban dokter terhadap teman sejawat (dua pasal)

4) Kewajiban doktcr terhadap diri sendiri (dua pasal)

5) Penutup (satu pasal)

Dalam menjalankan tugas profesionalnya, didasarkan pada niat baik yaitu berupaya dengan sungguhsungguh berdasarkan pengetahuannya yang dilandasi dengan sumpah dokter, kode etik kedokteran, dan standar profesinya untuk menyembuhkan/menolong pasien. Ada 3 hal yang dijadikan pedoman pertanggungjawaban oleh tenaga medis/ dokter dalam melaksanakan tugas fungsinya yaitu tanggung jawab etis, tanggung jawab profesi dan tanggung jawab hukum 


\section{Tanggung Jawab Etis}

Peraturan yang mengatur tanggung jawab etis dari seorang dokter adalah Kode Etik Kedokteran Indonesia.Kode Etik Kedokteran Indonesia dikeluarkan dengan Surat Keputusan Menteri Kesehatan No. 434/Menkes/SK/X/1983.Kode Etik Kedokteran Indonesia disusun dengan mempertimbangkan International Code of Medical Ethics dengan landasanideal Pancasila dan landasan struktural UUD 1945.Kode Etik Kedokteran Indonesia ini mengatur hubungan antarmanusia yang mencakup kewajiban umum seorang dokter, hubungan dokter dengan pasiennya, kewajiban dokter terhadap sejawatnya, dan kewajiban dokter terhadap diri sendiri.

Pelanggaran etik tidak selalu berarti pelanggaran hukum, sebaliknya pelanggaran hukum tidak selalu merupakan pelanggran etik kedokteran. Berikut diajukan beberapa contoh:

1. Pelanggaran Etik Murni: a).Menarik imbalan yang tidak wajar atau menarik imbalan jasa dari keluarga sejawat dan dokter gigi,b).Mengambil alih pasien tanpa persetujuan sejawatnya, c).Memuji diri sendiri di hadapan pasien,d). Tidak pernah mengikuti pendidikan kedokteran yang berkesinambungan, e). Dokter mengahaikan ktsehatannva sendiri, f).Pelanggaran Etikolegal,,g). Pelayanan dokter di bawah standar.h). Menertibkan surat keterangan palsu, i).Membuka rahasia jabatan atau pekerjaan dokter,j).Abortus provokatus.

\section{Tanggung Jawab Profesi} terkait dengan:

Tanggung jawab profesi dokter berkaitan erat dengan profesionalisme seorang dokter. Hal ini a). Pendidikan, Pengalaman, dan Kualiflkasi Lain

Dalam menjalankan tugas profesinya seorang dokter harus mernpunyai derajat pendidikan yang sesuai dengan bidang keahlian yang ditekuninya. Dengan dasar ilmu yang diperoleh semasa pendidikan yang ditekuninya di Fakultas Kedokteran maupun spesialisasi dan pengalamannya untuk menolong penderita.

b).Derajat Risiko Perawatan

Derajat risiko perawatan diusahakan untuk sekecil-kecilnya, sehingga efek samping dari pengobatan diusahakan minimal mungkin.Di samping itu, mengenai derajat risiko perawatan harus diberitahukan terhadap penderita maupun keluarganya, sehingga pasien dapat memilih alternatif dari perawatan yang diberitahukan oleh dokter.

c). Peralatan Perawatan

Perlunya digunakan pemeriksaan dengan menggunakan peralatan perawatan, apabila dari hasil pemeriksaan luar kurang didapatkan hasil yang akurat sehingga diperlukan pemeriksaan menggunakan bantuan alat.

\section{Tanggung Jawab Hukum}

Tanggung jawab hukum dokter adalah suatu "keterikatan" dokter terhadap ketentuan-ketentuan hukum dalam menjalankan profesinya.Tanggung jawab seorang dokter dalam bidang hukum terbagi tiga bagian, yaitu tnggung jawab hukum dokter dalam bidang hukurn perdata, pidana, dan adrninistrasi.

Tanggung jawab pidana di sini timbul bila pertama-tama dapat dibuktikan adanya kesalahan profesional, misalnya kesalahan dalam diagnosis atau kesalahan dalam cara-cara pengobatan atau perawatan. Dari segi hukum, kesalahan/kelalaian akan selalu berkait dengan sifat melawan hukumnya suatu perbuatan yang dilakukan oleh orang yang mampu bertanggungjawab apabila dapat menginsafi makna yang kenyataannya dari perbuatannya, dan menginsafi perbuatannya itu tidak dipandang patut dalam pergaulan masyarakat dan mampu untuk menentukan niat/kehendaknya dalam melakukan perbuatan tersebut.

Sehubungan dengan kemampuan bertanggung jawab ini, dalam menentukan bahwa seseorang itu bersalah atau tidak perbuatan yang dilakukan itu merupakan perbuatan yang dilarang oleh undang-undang dan adanya hubungan batin antara pelaku dengan perbuatan yang dilakukan yaitu berupa dolus (kesenjangan) atau culpa (kelalaian/kelupaan) serta tidak adanya alasan pemaaf. Mengenai kelalaian (negylience) mencakup dua hal vaitu karena melakukan sesuatu yang seharusnya tidak dilakukan atau karena tidak melakukan sesuatu yang seharusnya dilakukan. Kesalahan atau kelalaian tenaga kesehatan dapat terjadi di bidang hukum pidana, diatur antara lain dalain Pasal: 346, 347, 350), 360, dan:386 Kitab Undang-undang Hukum Pidana.

Ada perbedaan kepentingan antara tindak pidana biasa dan "tindak pidana medis".Pada tindak pidana yang terutama diperhatikan yaitu "akibatnya", sedangkan pada tindak pidana medis yaitu "penyebabnya".Walaupun berakibat fatal, tetapi jika tidak ada unsur kelalaian atau kesalahan maka dokternya tidak dapat dipersalahkan. Beberapa contoh dari criminal malpractice yang berupa kesenjangan 
yaitu melakukan aborsi tanpa indikasi medis, meinbocorkan rahasia kedokteran, tidak melakukan pertolongan seseorang yang dalam keadaan emergency, melakukan euthanasia, menerbitkan surat keterangan dokter yang tidak benar, membuat visum et reperhum yang tidak benar, dan memberikan keterangan yang tidak benar, di sidang pengadilan dalam kapasitas sebagai ahli.

Sebagai contoh dalam menganalisis apakah perbuatan dokter itu mengandung tanggung jawab pidana apa tidak, yaitu dalam hal melakukan pembedahan. Persoalan pokok yang perlu dikemukakan yaitu pembedahan dengan indikasi medis. Apakah hal itu dilakukan dokter terhadap pasien, maka perbuatan dokter tersebut dapat dibenarkan. Adapun jika pembedahan dilakukan tanpa melalui indikasi medis, maka perbuatan dokter tersebut dipidanakan.

Praktik kedokteran mengombinasikan sains dan seni, sains dan teknologi adalah bukti dasar atas berbagai masalah klinis dalam masyarakat. Seni kedokteran adalah penerapan gabungan antara ilmu kedokteran, intuisi, dan keputusan medis untuk menentukan diagnosis yang tepat dan perencanaan perawatan untuk masing-masing pasien serta merawat pasien sesuai dengan apa yang diperlukan olehnya.

Konsil Kedokteran Indonesia (KKI) berdasarkan Undang-Undang Nomor 29 Tahun 2004 tentang Praktik Kedokteran telah dibentuk untuk melindungi masyarakat penerima jasa pelayanan kesehatan dan meningkatkan mutu pelayanan kesehatan dari dokter dan dokter gigi, yang terdiri dari kansil kedokteran dan kansil kedokteran gigi. Tidak dapat disangkal lagi bahwa dengan berlakunya Undang-undang praktik kedokteran, maka apa yang menjadi norma atau kaidah-kaidah bagi setiap dokter atau dokter gigi baik sebagai individu manpun sebagai organisasi profesi. Sebagai individu pengemban ilmu pengetahuan kedokteran dalam penerapannya maupun sebagai individu dalam pergaulan mayarakat di bidang praktik kedokteran telah diatur di dalam Undang-Undang Nomor 29 Tahun 2004 tentang Praktik Dokter.

Mengenai hak dan kewajiban dokter ini diatur dalam Pasal 50-51 Undang-Undang Nomor 29 Tahun 2004 tentangPraktik Dokter, Pasal 50 menjelaskan bahwa: "dokter atau dokter gigi dalam melaksanakan praktik kedokteran mempunyai hak:"

a. Memperoleh perlindungan hukum sepanjang melaksanakan tugas sesuai dengan standar profesi dan standar prosedur operasional.

b. Memberikan pelayanan medis menurut standar profesidan standar prosedur operasional.

c. Memperoleh informasi yang lengkap dan jujur dari pasier.atau keluarganya,

d. Menerima imbalan jasa.

Adapun dalam Pasal 51 menjelaskan bahwa:" "dokter atau dokter gigi dalam melaksanakan praktik kedokteran mempunyai kewajiban:"

a. Memberikan pelayanan medis sesuai dengan standar profesi dan standar prosedur operasional serta kebutuhan medis pasien.

b. Merujuk pasien ke dokter atau dokter gigi lain yang mempunyai keahlian atau kemampuan yang lebih baik, apalagitidak mampu melakukan suatu pemeriksaan atau pengobatan.

c. Merahasiakan segala sesuatu yang diketahuinya tentangpasien, bahkan juga setelah pasien itu meninggal dunia.

d. Melakukan pertolongan darurat atas dasar perikemanusian, kecuali bila is yakin ada orang lain yang bertugas dan mampu melakukannya dan.

e. Menambah ilmu pengetahuan dan mengikuti perkembangan ilmu kedokteran atau kedokteran gigi

Mengenai hak dan kewajiban pasien diatur dalam Pasal 52-53 Undang-Undang Nomor 29 Tahun 2004 tentang Praktik Kedokteran. Pasal 52 menjelaskan bahwa: "pasien, dalam menerima pelayanan pada praktik kedokteran, mempunyai hak:"

a. Mendapatkan penjelasan secara lengkap tentang tindakan medis sebagaimana dimaksud dalam Pasal 45 ayat (3).

b. Meminta pendapat dokter atau dokter gigi lain.

c. Mendapatkan pelayanan sesuai dengan kebutusan medis.

d. Menolak tindakan medis

e. Mendapatkan isi rekarn medis.

Adapun dalarn Pasal 53 menjelaskan bahwa: "pasien, dalam menerima pelayanan pada praktik kedokteran mempunyai kewajiban:"

a. Memberikan informasi yang lengkap dan jujur tentang masalah kesehatannya.

b. Mematuhi nasihat dan petunjuk dokter atau dokter gigi.

c. Mematuhi ketentuan yang berlaku di sarana pelayanan kesehatan,

d. Memberikan imhalan jasa atas pelayanan yang diterima. 


\section{Akibat Hukum Dari Perjanjian Tindakan Medis Dokter terhadap Pasien Yang Dirawat di Rumah Sakit}

Dalam Pasal 1 ayat (1) Undang-Undang Nomor 29 Tahun 2004 tentang Praktik Kedokteran menjelaskan: "praktik kedokteran adalah rangkaian kegiatan yang dilakukan oleh dokter dan dokter gigi terhadap pasien dalam melaksanakan upaya kesehatan." Adapun dalam ayat (2) menjelaskan pengertian dokter yaitu: "dokter dan dokter gigi adalah dokter, dokter gigi, dan dokter gigi spesialis lulusan pendidikan kedokteran atau kedokteran gigi baik di dalarn maupun di luar negeri yang diakui oleh Pemerintah Republik Indonesia sesuai dengan peraturan perundang-undangan."

Asas dan tujuan dari hukum kedokteran ini terutama di atur dalam Undang-Undang Nomor 29 tahun 2004 tentang Praktik Kedokteran dalam Pasal 2 menjelaskan: "praktik kedokteran dilaksanakan berasaskan Pancasila dan didasarkan pada nilai ilmiah, manfaat, keadilan, kemanusiaan, keseimbangan, serta perlindungan dan keselamatan pasien." Adapun dalarn Pasal 3 menjelaskan tujuan pengaturan praktik kedokteran ini bertujuan untuk:

a. Memberikan perlindungan kepada pasien.

b. Mempertahankan dan meningkatkan mutu pelayanan medis yang diberikan oleh dokter dan dokter gigi.

c. Memberikan kepastian hukum kepada masyarakat, dokter,dan dokter gigi.

Dalam bidang kedokteran, dikenal sejak lama suatu cabang ilmu yaitu kedokteran forensik atau dahulu disebut ilmu kedokteran kehakiman. Cabang ilmu ini merupakan disiplin ilmu kedokteran, yang peranannya yaitu membantu hakim atau proses peradilan, antara lain karena tidak mungkin barang bukti tertentu dibawa ke ruang sidang. Oleh karena itu, dokter membuat suatu visum et repertum sebagai pengganti.

Hukum kedokteran forensik adalah hukum yang mempelajari hubungan yuridis, di mana seorang dokter merupakan bagian dari hukum antara dokter dan pasien dan berhubungan dengan hukum pidana. Hukum kedokteran forensik atau hukum kedokteran kehakiman ialah mempelajari hukurn kedokteran kehakiman dalam proses peradilan di mana atas dasar keahlian di bidang ilmu tertentu diberi kepercayaan untuk ikut serta dalam proses penegakan hukum baik itu dengan visum maupun menjadi saksi ahli secara substantif. Hukum kedokteran forensik fokus pada persoalan-persoalan tindak pidana yang berakibat pada terjadinya luka-luka atau cacat pada seseorang ataupun mengakibatkan nyawa melayang sehingga ilmu forensik mampu menganalisis dan mengetahui penyebabnya dengan visum.

Hukum kedokteran, sebagai bagian dari hukum kesehatan yang terpenting, meliputi ketentuan hukum yang berhubungan dengan pelayanan medis.Hukum kedokteran disebut juga hukum kesehatan dalain arti sempit.Apabila objek hukum kesehatan yang pelayanan kesehatan, maka objek hukum kedokteran adalah pelayanan medis. Oleh karena pengertian hukum kesehatan lebih luas dari pada hukum kedokteran dan juga meliputi ketentuan-ketentuan hukum yang berhubungan dengan pemeliharaan kesehatan, di dalamnya terdapat bidang hukum lain seperti hukum rumah sakit, hukum keperawatan, hukum farmasi, hukum kesehatan lingkungan, dan hukum keselamatan kerja. Hukum kedokteran dianggap bagian terpenting karena hampir selalu terdapat persinggungan atau daerah-daerah kelaba antara hukum kedokteran dan bidangbidang hukum lainnya, yang tidak demikian halnya antara bidang-bidang hukum yang lain tersebut.

Dokter sebagai tenaga profesional adalah bcrtanggung jawab dalam setiap tindakan medis yang dilakukan terhadap pasien.Dalam menjalankan tugas profesionalma, didasarkan pada niat baik yaitu berupaya dengan sungguh-sungguh herdasarkan pengetahuannya yang dilandasi dengan sumpah dokter, kode etik kedokteran, dan standar profesinya untuk menyembuhkan/menolong pasien Ada 3 hal yang berkaitan dengan tanggung jawab yang dijadikan pedoman dalam praktek informed Consent yang dialkukan dokter terhadap pasiennya antara lain: tanggung jawab etis, tanggung jawab profesi dan tangung jawab hukum.

Peraturan yang mengatur tanggung jawab etis dari seorang dokter adalah Kode Etik Kedokteran Indonesia.Kode Etik Kedokteran Indonesia dikeluarkan dengan Surat Keputusan Menteri Kesehatan No. 434/Menkes/SK/X/1983.Kode Etik Kedokteran Indonesia disusun dengan mempertimbangkan International Code of Medical Ethics dengan landasanideal Pancasila dan landasan struktural UUD 1945.Kode Etik Kedokteran Indonesia ini mengatur hubungan antarmanusia yang mencakup kewajiban umum seorang dokter, hubungan dokter dengan pasiennya, kewajiban dokter terhadap sejawatnya, dan kewajiban dokter terhadap diri sendiri.

Tanggung jawab hukum seorang dokter adalah suatu "keterikatan" dokter terhadap ketentuanketentuan hukum dalam menjalankan profesinya.Tanggung jawab seorang dokter dalam bidang hukum terbagi tiga bagian, yaitu tanggung jawab hukum dokter dalam bidang hukum perdata, pidana, dan administrasi. 
Tanggung jawab pidana di sini timbul bila pertama-tama dapat dibuktikan adanya kesalahan profesional, misalnya kesalahan dalam diagnosis atau kesalahan dalam cara-cara pengobatan atau perawatan. Dari segi hukum, kesalahan/kelalaian akan selalu berkait dengan sifat melawan hukumnya suatu perbuatan yang dilakukan oleh orang yang mampu bertanggungjawab apabila dapat menginsafi makna yang kenyataannya dari perbuatannya, dan menginsafi perbuatannya itu tidak dipandang patut dalam pergaulan masyarakat dan mampu untuk menentukan niat/kehendaknya dalam melakukan perbuatan tersebut.

Sehubungan dengan kemampuan bertanggung jawab ini, dalam menentukan bahwa seseorang itu bersalah atau tidak perbuatan yang dilakukan itu merupakan perbuatan yang dilarang oleh undang-undang dan adanya hubungan batin antara pelaku dengan perbuatan yang dilakukan yaitu berupa dolus (kesenjangan) atau culpa (kelalaian/kelupaan) serta tidak adanya alasan pemaaf. Mengenai kelalaian (negylience) mencakup dua hal vaitu karena melakukan sesuatu yang seharusnya tidak dilakukan atau karena tidak melakukan sesuatu yang seharusnya dilakukan. Kesalahan atau kelalaian tenaga kesehatan dapat terjadi di bidang hukum pidana, diatur antara lain dalain Pasal: 346, 347, 350), 360, dan:386 Kitab Undang-undang Hukum Pidana.

Ada perbedaan kepentingan antara tindak pidana biasa dan "tindak pidana medis".Pada tindak pidana yang terutama diperhatikan yaitu "akibatnya", sedangkan pada tindak pidana medis yaitu "penyebabnya".Walaupun berakibat fatal, tetapi jika tidak ada unsur kelalaian atau kesalahan maka dokternya tidak dapat dipersalahkan. Beberapa contoh dari criminal malpractice yang berupa kesenjangan yaitu melakukan aborsi tanpa indikasi medis, meinbocorkan rahasia kedokteran, tidak melakukan pertolongan seseorang yang dalam keadaan emergency, melakukan euthanasia, menerbitkan surat keterangan dokter yang tidak benar, membuat visum et reperhum yang tidak benar, dan memberikan keterangan yang tidak benar, di sidang pengadilan dalam kapasitas sebagai ahli.

Sebagai suatu ilustrasi dalam menganalisis apakah perbuatan dokter itu mengandung tanggung jawab pidana apa tidak, yaitu dalam hal melakukan pembedahan. Persoalan pokok yang perlu dikemukakan yaitu pembedahan dengan indikasi medis.Apakah hal itu dilakukan dokter terhadap pasien, maka perbuatan dokter tersebut dapat dibenarkan.Adapun jika pembedahan dilakukan tanpa melalui indikasi medis, maka perbuatan dokter tersebut dipidanakan.

Memperhatikan kedudukan hukum para pihak dalam hal pelayanan medik sebagaimana diatur dalam UndangUndang Nomor 23 Tahun 1992 dan Undang-Undang Nomor 29 Tahun 2004, maka yang perlu diperhatikan yaitu adanya berbagai faktor yang telah berperan sehingga terjadi perubahan pada hubungan antara dokter dengan pasien, misalnya faktor ekonomis, pertumbuhan di dalam masyarakat itu sendiri, sikap pribadi pasien terhadap dokter baik terhadap pelayanannya itu sendiri maupun dalam berkomunikasi. Selain itu para dokter seringkali mempunyai perasaan tertentu yang tidak dapat ditunjukkan dalam hubungannya dengan seorang pasien, misalnya kekecewaan terhadap hasil perawatan yang telah diberikannya, antipati dan simpati, perasaan takut, khawatir untuk mengatakan yang sebenarnya.Kebiasaan untuk menahan perasaan itu mempunyai pengaruh terhadapsikap dokter kepada pasiennya.Selanjutnya posisi yang lebih kuat dari para dokter itu juga mempunyai pengaruh terhadap hubungan antara dokter dengan pasien baik disadari maupun tidak disadari terbuka peluang bagi dokter untuk memanipulir pasiennya.Terlebih lagi didukung oleh adanya perasaan takut dari pasien mengenai penyakitnya (Leenen, 1991: 65-66).

Dapat juga terjadi, adakalanya sikap dari pasien mempengaruhi hubungan antara dokter dengan pasien.Pasien seringkali kurang mau melihat masalah kemungkinan pemberian bantuan itu menurut pandangan seorang dokter, dan kurang terbuka terhadap dokter yang merawatnya, karena kurangnya pengertian.Oleh karena itu menurut Leenen hubungan antara dokter dengan pasien harus dipandang sebagai suatu kerjasama yang berada dibawah pengaruh faktor-faktor tersebut diatas, sehingga dapat dikatakan bahwa kedudukan para pihak dalam kerjasama yang demikian adalah tidak sederajat.

Apa yang dikatakan Leenen tersebut diatas, hal ini di Indonesia merupakan suatu fakta dan kenyataan mungkin dikarenakan masalah faktor pendidikan, budaya, agama, ekonomi maupun masalah komunikasi. Faktor budaya yang menonjol antara lain adalah masalah bahwa kebanyakan masyarakat Indonesia secara tidak langsung menganggap dokter memiliki status yang lebih tinggi karena kemampuan dan pengalamannya di bidang pengobatan. Biarpun pasien tidak menganggap bahwa dokter sebagai Dewa Penolong.Namun sebenamya harus diingat bahwa kedudukan dokter dan pasien secara hukum (perdata) dalam pemberian pelayanan medik adalah sederajat Hubungan itu pada hakekatnya mengatur semua hubungan hukum yang dilakukan oleh setiap subyek hukum (dokter dan pasien).Termasuk pula didalamnya seorang dokter yang sedang melaksanakan profesinya, baik dalam pengobatan maupun dalam penelitian klinis dan penelitian biomedik non klinis.Tanggung jawab hukum yang dimaksudkan disini adalah tanggung jawab hukum yang berkaitan dengan profesinya yaitu dalam hal memberikan pelayanan medik, yang persyaratannya diatur dalam suatu perjanjian sebagaimana terdapat dalam pasal 1313 KUH PERDATA, 1320 KUH PERDATA, dan 1365 KUH PERDATA. 
Sehubungan dengan adanya resiko tinggi dalam pelayanan medik yang berkaitan dengan tanggung jawab dokter selaku profesional, Mertokusumo (1988: 9) dengan memperhatikan pendapat Hoge Raad adanya pembatasan tanggung jawab dalam hubungan hukum yaitu : (1) beratnya kesalahan, (2) sifat dan isi perjanjian, (3) kedudukan dalam masyarakat serta hubungan antara para pihak satu sama lain, (4) terjadinya syarat pembatasan/eksonerasi, (5) besamya kesadaran pihak lain akan maksud dan syarat yang bersangkutan.

Dari beberapa pengertian diatas, pembatasan tanggung jawab atau eksonerasi tidak berlaku bagi kerugian yang terjadi sebagai akibat dari suatu kesalahan ataupun kelalaian.Pembatasan tanggung iawab hanya dimungkinkan karena resiko, yang pada azasnya hanya berlaku bagi para pihak.Dengan semakin majunya ilmu dan teknologi kedokteran di satu pihak, serta semakin baiknya tingkat pendidikan dan keadaan sosial ekonomi masyarakat di lain pihak, maka syarat mutu semakin bertambah penting.

Menurut Leenen, bahwa apa yang dikenal dalam dunia kedokteran sebagai "lege artis" pada hakekatnya adalah suatu tindakan yang dilakukan sesuai dengan standar profesi medik (SPM) yang padi hakekatnya terdiri dari beberapa unsur utama yaitu:

1. Bekerja dengan teliti, hati-hati dan seksama

2. Sesuai dengan ukuran medis

3. Sesuai dengan kemampuan rata-rata/sebanding dengan dokter dalam kategori keahlian medik yang sama

4. Dalam keadaan yang sebanding, dan

5. Dengan sarana dan upaya yang sebanding wajar dengan tujuan konkrit tindak medik tersebut.

Seorang dokter yang menyimpang dari SPM dikatakan telah melakukan kelalaian atau kesalahan dan hal ini menjadi salah satu unsur malpraktik medik, yakni apabila kesalahan atau kelalaian itu bersifat sengaja (dolus) serta menimbulkan akibat yang serius atau fatal pada pasien.Beberapa penulis membedakan pengertian kelalaian (negligence) dengan kesalahan (error) karena dalam kelalaian terkandung unsur-unsur utama tidak hati-hati, tidak peduli, tidak tahu atau tidak acuh, sedangkan pada kesalahan unsur utamanya adalah kekeliruan. Seorang dokter yang melanggar dan menyimpang dari SPM dikatakan telah melakukan kesalahan profesi atau malpraktik medik, tetapi belum tentu malpraktik pidana. (untuk pemidanaan suatu malpraktik medik diperlukan pemhuktian adanya unsur kelalaian berat (culpa lata) yang berakibat fatal dan serius. Standar profesi medik (SPM) biasanya disusun oleh perhimpunan profesi, namun ada rumah sakit yang membuat sendiri semacam standar profesi medik dalam bentuk pedoman diagnosa dan terapi.

Sehubungan standar profesi medik tersebut, di dalam Undang - Undang Nomor 23 Tahun 1992 Pasal 53 ayat 2 disebutkan: "Tenaga kesehatan dalam melakukan tugasnya berkewajiban untuk rnemenuhi standar profesi dan menghormati hak pasien“. Sedangkan dalam Undang-Undang Nomor 29 Tahun 2004 pada Pasal 50 sub b disebutkan: "Dokter atau dokter gigi dalam melaksanakan praktik kedokteran mempunyai hak : memberikan pelayanan medis menurut standar profesi dan standar prosedur operasional”. Juga pada Pasal 51 Undang-Undang Praktik Kedokteran disebutkan bahwa dokter atau dokter gigi dalam melaksanakan praktik kedokteran mempunyai kewajiban memberikan pelayanan medis sesuai dengan standar profesi dan standar prosedur operasional serta kebutuhan medis pasien ( Pasal 51 sub a)

\section{SIMPULAN DAAN SARAN}

\section{Simpulan}

1. Perjanjian Tindakan Medis (Inform consent) dilaksanakan sesuai dengan prosedur dan berpedoman berdasar peraturan perundangan, kode etik yang berlaku. Dengan demikian dokter terikat dengan kode etik profesi dalam melaksanakan tugas pokok fungsinya sebagai tenaga medis. Selain itu, dokter yang bertugas di Rumah Sakit dalam melakukan perawatan dan tindakan medis serta Pasien yang dirawat dirumah sakit masing masing mempunyai hak dan kewajiban. Dalam melaksanakan tindakan tindakan medis yang akan dilaksanakan melibatkan dokter dan pasien yang dirawat, harus ada kata sepakat dan tertulis untuk dilaksanakan oleh kedua belah pihak

2. Akibat hukum bagi para pihak, yaitu dokter dan pasien setelah tindakan medis dilaksanakan adalah berupa tanggung jawab hukum. Tanggung jawab hukum dokter adalah suatu "keterikatan" dokter terhadap ketentuan-ketentuan hukum dalam menjalankan profesinya.Tanggung jawab seorang dokter dalam bidang hukum terbagi tiga bagian, yaitu tanggung jawab hukum dokter dalam bidang hukum perdata, pidana, dan adrninistrasi. Adapun yang penulis maksudkan disini adalah tanggung jawab hukum yang berkaitan dengan profesinya yaitu dalam hal memberikan pelayanan medik, yang persyaratannya diatur dalam suatu perjanjian sebagaimana terdapat dalam pasal 1313 KUH PERDATA, 1320 KUH PERDATA, dan 1365 KUH PERDATA 


\section{Saran saran}

1. Dalam melaksanakan tindakan medis senantiasa harus berpedoman pada produk peraturan perundangan dan peraturan lainnya yang terkait dengan Perjanjian Tindakan Medis (informed consent) untuk meminimalisir dan meniadakan kesalahan prosedur dalam menangani pasien

2. Diperlukan adanya Legal konsultan yang berbasis kesehatan untuk memberikan penguatan kepada tenaga medis yang bertugas untuk memberikan pembelaan dan advokasi jika terjadi tuntutan dari pihak pasien dan keluarganya

\section{DAFTAR PUSTAKA}

\section{Buku}

Amirudin dan Zainal Asikin. 2003. Pengantar Metode Penelitian Hukum., Raja Grafindo Persada Jakarta

Azwar A, 1994. Standar Pelayanan Medik Materi Pelatihan, Penerapan Standart Pelayanan Rumah Sakit, Medis dan Pengawasan Etik, Ujung Pandang

Bahder Johan Nasution,2005. Hukum Kesehatan Pertanggungjawaban Dokter, Rineka Cipta, Jakarta,

Dalmy Iskandar,1998. Hukum Rumah Sakit dan Tenaga Kesehatan,Sinar Grafika Jakarta

Danny Wiraddharma, dan Dionisia Sri Hartati , 2010. Penuntun Kuliah Hukum Kedokteran , Sagung Seto Jakarta

Endang Kusuma Astuti,2003. Tanggung Jawab Hukum Dokter dalam Upaya Pelayanan Medis kepada Pasien: Aneka Wacana Tentang Hukum, Kanisius Yogyakarta.

Hermien Hardiati Koeswadji, 1998. Hukum Kedokteran. Studi Tentang Hubungan Hukum dalam mana Dokter sebagai salah satu fihak, Aditya Bakti Jakarta.

Hermien Hardiati Koeswadji,1984. Hukum dan Masalah Medis, Universitas Airlangga, Surabaya,

Hendrojono Soewono,2007. Batas Pertanggungjawaban Hukum Malpraktek Dokter Dalam Transaksi Terapeutik, Srikandi, Cet.I

Inu Kencana Syafii, 1999. Pengantar Ilmu Pemerintahan PT Eresco Jakarta

Ljian Poltak Sinambela,2006. Reformasi pelayanan Publik, Teori Kebijakan dan Implementasi, Bumi Aksara Jakarta.

Leenen, H.J.J., Lamintang, PAF, 1991. Pelayanan Kesehatan dan Hukum, Bina Cipta, Jakarta

Ninik Maryati, 1998. Malapraktik Kedokteran dari Segi Hukum Pidana dan Perdata, Bina Aksara, Jakarta

Pamudji, 1994. Perbandingan Pemerintahan, Bumi Aksara Jakarta

Ratminto dan Atik Septiwinarsih,Manajemen Pelayanan Publik, Yogyakarta ,2006

Sri praptaningsih, 2006. Kedudukan Hukum Perawat Dalam Upaya Pelayanan Kesehatan di Rumah Sakit ,Rajawali Press, Jakarta

SF Marbun,et.al, Dimensi Pemikiran Hukum Administrasi Negara, UII Press Jakarta 2005

Sampara Lukman . 2005. Pengembangan Pelaksanaan Pelayanan Prima,LAN Jakarta

Sabir Alwy, 2006. Kemitraan Dalam Hubungan Dokter Pasien, Penerbit Rineka Cipta Jakarta.

Soerjono Soekanto, 1983. Dualisme Penelitian Hukum Normatif \& Empiris Jakarta, Pustaka Pelajar,

Sri Siswati, 2015. Etika dan Hukum Kesehatan Dalam Perspektif Undang Undang Kesehatan,PT Raja Grafindo Persada, Jakarta Cet. 2

Titik Triwulan Tutik,Perlindungan Hukum Bagi Pasien, Prestasi Pustaka Publisher, Jakarta, 2010.

Trini Handayan, 2012. Fungsionalisasi Hukum Pidana Terhadap Perbuatan Perdagangan Organ Tubuh Manusia, Mandar Maju, Bandung

Yustina Sri Hartini, Sulasmono, 2010. Praktek Kefarmasian Ulasan peraturan Tentang Bidang Pekerjaan Apoteker, Sanata Dharma Yogyakarta

\section{Peraturan Perundang Undangan}

Undang Undang Dasar Negara R I 1945

Kitab Undang-Undang Hukum Perdata

Undang Undang No 29 Tahun 2004 Tentang Praktik Kedokteran

Undang Undang No 44 Tahun 2009 Tentang Rumah Sakit

Undang Undang No 25 Tahun 2009 Tentang Pelayana Publik

Undang Undang No 36 Tahun 2009 Tentang Kesehatan 